\title{
Bread and Breath: Two Reflections on the Ethics of (Doing) History
}

\author{
Rachel Buchanan and Maria Tumarkin
}

Introduction: This article developed from the conversations we have had with each other about history. How do we make it? Why do we make it? Who is history for? The 'bread' in the title refers to blessed, complicated moments of challenge or revelation for each of us, difficult epiphanies in which we have had to reconsider the ethics of our research, the location of our sources (the archive or the body, the oral history interview or the song) and the multiple ways in which historical knowledge can be transmitted. The 'breath', in turn, speaks of human life, which, after all, is the basic, indivisible cell of any history; it speaks too of the precious, often intangible quality of the connections we make with the past.

Really, what we want to know is this - how does history make us, and what is at stake, for us, when we make history? This article is a dialogue in which we try to listen to each other and respond to the different moments we recount. Although our concerns are different-Rachel Buchanan argues it is not always ethical to collect oral histories but there are ethical concerns, too, when a historian feasts in the archives; while Maria Tumarkin considers whether the institutionalised ethics of historical research in academia can blind us to the deeper, more fundamental ethical demands of working with the past - both of us feel that, in essence, we are talking, and worrying, about the same things. Bread and breath. The mutual, life-giving dependence of the past and the present.

Is the question of ethics in scholarly research fetishised, its considerable prominence of late a fad? We don't think so. For some time now we have been listening to each other recount moments and encounters that had pushed us to the limits, made us 'open to all the winds ... [with] no shelter, no protection' (Pinter 2005). And in all the talking and listening, determined not to look away from these moments and encounters, we have discovered, to our surprise, that it is the notion of sustenance that has asserted itself as a central ethical idea. The 'bread' in the title then refers to the meaning and uses of stories, memories and archives that, as historians, we seek to connect to, and to understand. And all that 'bread' evokes - the taking and the giving of it, the feeding and the going without - is a reminder, which both of us welcome, of just how high the stakes are when we engage with the past. 
Rachel Buchanan: On 18 October 2009, a cold Sunday morning, my parents, my eldest daughter and I set off south from New Plymouth along the Surf Coast Highway on our way to Parihaka. On the 18th of every month, there's a hui (meeting) at the Maori settlement to mark Te Whiti's ra day. The tradition is long-standing, the date significant. It was chosen to commemorate the day, in March 1860, when British soldiers fired the first shot in the first Taranaki War at Waitara, a township north of Parihaka on the central West Coast of New Zealand's North Island.

These meetings started in the late 1860s when the non-violent pa (village) was set up by political and spiritual leaders Te Whiti o Rongomai and Tohu Kakahi as a place for what Te Whiti called 'a different kind of peace, a fighting peace' (Riseborough, Resistance 231). By the late 1870s these hui had grown into enormous meetings - political rallies, prayer services, history lessons, feasts - attended by up to 4000 Maori from all around New Zealand. Both leaders spoke but it was Te Whiti who had the talent as an orator. His voice was mesmerising, spellbinding and enchanting. He was handsome and urbane, a master of metaphor, a lover of architecture, a connoisseur of symbolic political action, a news junkie and a visionary town planner who in the late 1880 s oversaw the construction of a reservoir and hydraulic dam, the building of roads and the installation of electric lights at the settlement (Scott 185-192). This reconstruction followed te pahua (the plunder), the Crown's 1881 invasion and ransacking of Parihaka. On the morning of 5 November 1881, 945 volunteers and 644 Armed Constabulary marched into the pa and were greeted by singing children and women carrying warm bread baked for the soldiers. Many of the militia-men were military settlers from Melbourne, lured across the Tasman by the promise of soldier-settler farms on confiscated Maori land.

State Highway 45, the narrow road my dad was driving on, was built by armed constabulary in the 1870s as a precursor to the invasion of Parihaka. Were we invaders too? I was so terrified. I held my spiral-bound, typeset manuscript in my lap. It contained many errors. For instance, the name of the settlementParihaka - was spelt incorrectly on the top left margin of each page. I thought about who might receive the manuscript and what they might say about it. A warm reception was one option. A lukewarm one was another. So too was rebuke, rebuff or even eviction. Relatives have told me that Taranaki people sometimes threw stones at unwanted visitors. My first research visit to Parihaka was in 2002. I was a new PhD student and a new mother. The visit had not gone well. My eagerness, arrogance and naivety - as well as the divisive internal politics of the place - had culminated in a terrible argument with Parihaka historian Te Miringa Hohaia. I sketch a very edited version of this visit in the first chapter of my book (Parihaka Album 3-8). 
The details of that exchange were no longer so sharp but the feelings it generated were. There was the cringing sense of failure and outrage, the anger, the hunt for people to blame and the selfish fear that I had totally stuffed up the chance of getting any help from people at Parihaka, especially from Te Miringa, a kaumatua (leader) who had lodged one of the first Treaty of Waitangi claims back in the 1970s and had also been an instigator of a landmark exhibition, Parihaka: The Art of Passive Resistance, at City Gallery, Wellington in 2000. Later, once I got back to Melbourne, there was the guilt at my own stupidity.

These unpleasant feelings washed through me as we drove along all these years later; the baby I had nursed on that first trip was now a fair, watchful eightyear-old, Lily Arapera. On top of these old feelings, or maybe beneath them like a concrete foundation, was the great, immovable slab of my ignorance. A PhD had done nothing to shift the slab. If anything, it had made it worse. I kept thinking about the huge concrete foundation of Te Raukura, all that now remains at Parihaka of Te Whiti's once magnificent Victorian meeting house. In 1927 a journalist described it as 'a decaying castle of charm'. In 1960 it burnt down, taking the life of caretaker George Te Kahui Pokai Aitua with it (Buchanan, Parihaka Album 148, 139).

What sort of a caretaker had I been of the story of Parihaka? Who did I think I was, taking a manuscript to this place, this pa, this living memorial to the ravages of war in Taranaki, this historic site, this refugee camp, this beautiful ruin? What would I say about my work to the audience here? Forget about the objective, distant, expert, academic, third-person narrator, forget about hiding behind theory, forget about showing off about how many books or archival documents I'd read. No one cared. None of that mattered. Actually, that's not quite true. A mastery of theory did matter: as Nepia Mahuika has recently argued, excellence matters and breadth of engagement matters (24-40). But what mattered much more was my intentions, the context for my research and the usefulness of my research for this community in the present and into the future, all ethical questions raised by Linda Tuhiwai Smith in her seminal work, Decolonizing Methodologies (9-10). Smith's book is written for indigenous researchers, 'primarily to help ourselves' (17). The trouble is that I am not an insider, an indigenous researcher in the Smith mould, but nor am I an outsider. I am someone in-between, someone raised in a mostly Pakeha world, someone who has had to work to reconnect with my relatives in Te Ao Maori (the Maori world) and to learn about whakapapa (genealogy), and then think about what kind of obligations my whakapapa might place on me as a researcher as well as what kind of privileges it might bring.

My publisher was Maori-owned and Maori-run. I was making this trip to Parihaka on the advice of a cousin, archivist and Taranaki reo (Taranaki Maori language) advocate Honiana Love. I had taken on Parihaka as a research topic 
with every intention of being humble and writing and researching using the kaupapa Maori techniques Smith argues for in Decolonizing Methodologies. Yet my first research trip to Parihaka showed I had a long way to go. It is common, in New Zealand at least, to connect oral history with Maori history as if historical evidence exists, primarily, in the bodies and minds of indigenous people (rather than in archives) and this history then needs to be extracted through interviews or testimonies. The requirements of the Waitangi Tribunal, New Zealand's commission of inquiry into contemporary and historic breaches of the 1840 Treaty signed between Maori chiefs and the Crown, and the work of eminent historians such as Judith Binney, reinforce this connection between oral history and Maori people.

In the 1990s, when the Tribunal sat at Parihaka, Maori were required to submit a 'traditional history' report with their claim. These reports had to detail genealogy, geography, customary practices, warfare, alliances, migrations and so on, both pre- and post-1840. In 1999, the tribunal's chief historian, Dr Grant Phillipson, suggested claimants research these reports by interviewing kaumatua and kuia (senior women) and consulting whakapapa books or other written sources in tribal possession. In a later article, Phillipson wrote: 'There are many varieties of oral evidence, some of it presented by Crown eyewitnesses to historical events; but on the whole it is considered the domain of Maori claimants' ('Talking' 42). This evidence could include oral traditions transmitted in the home or on the marae (meeting place) and 'ceremonial songs and orations that illustrate a context or create powerful moods or impressions' ('Talking' 41).

Likewise, Binney's landmark scholarship, including her most recent book on Te Urewera, her work on Te Kooti, her journal articles and even her first book, Nga Morehu, all rely, to varying degrees, on Maori informants who correct, interpret or make meaning from written or visual records or from Maori oral sources, such as waiata (songs) or whakatauki (proverbs), that have been written down. The title of an important 1987 essay by Binney on her work with Maori at Maungapohatu in the Ureweras makes the point explicit: 'Maori Oral Narratives, Pakeha Written Texts: Two Forms of Telling History'. In 1993, in a paper presented at Te Niho o Te Ati Awa, one of the three marae still functioning at Parihaka, historian Hazel Riseborough argued that 'Pakeha sources' were biased and could only tell a partial story about Parihaka. The full story, what Riseborough described as a 'true picture' could only be 'painted by you, te iwi kainga [the people of Parihaka], from sources available only to you-your oral sources, especially your waiata'.

The work of Binney and Riseborough and the processes of the tribunal shaped my early research strategies: Maori stories in the flesh; Pakeha stories on the paper! Maori had memory; Pakeha had history! I had gained the necessary ethics clearance from Monash University and in 2002 assumed that I would 
begin recruiting informants at Parihaka, descendants of people at the place during te pahua, people that could provide me with a 'true picture'. I had interviewed hundreds of people as a newspaper journalist-mostly quick, off-the-cuff encounters, but also some very intense interactions lasting several days - but I was confident these 'oral history' interviews would be different, more ethical and meaningful (Mahar 3-8). But my argument with Te Miringa taught me a lesson or two. By 2008, when I had started to write my book, I understood that there was no 'true picture' of Parihaka. There was no definitive insider account. Every account, including mine, would be subject to debate and dispute. Parihaka was/is a prophetic community, so there is no conclusion to the story, no agreed resolution. It is open-ended and fluid.

This lesson came later though. The first thing the argument taught me was that I had no right to waltz into Parihaka and ask elderly strangers, many of whom were living in very basic housing, to tell me all about their pain and suffering. I quickly understood that if I wanted people to trust me and talk with me, I would have to be prepared to offer something in return. In short, I would need to move back to New Zealand, I would need to learn Maori and I would need to be prepared to put in a lot of unpaid work on the marae. I was unable to make these commitments but I did not want to give up on my research. So, from 2002 on, the challenge was to figure out how I could write a Maori and Pakeha history of Parihaka just the same. Eventually I came to understand that I could speak with Parihaka people, both living and dead, in the archives, especially in the anti-colonial archives created through the work of the Waitangi Tribunal and through Maori-led history-making in art galleries and museums. Te Miringa Hohaia was a major contributor in all these fields.

This was how I tried to be ethical. Although I stayed in touch with Te Miringa and sometimes sought his advice, I decided to ask for very little. Also, I decided to pursue, with determination, any of my family's Maori connections with either Taranaki or Wellington, and see where this work took me. But still. I worried as we drove along. In 1999 Smith wrote of how indigenous communities and activists thought about research: 'At a common sense level research was talked about in terms of its absolute worthlessness to us, the indigenous world, and its absolute usefulness to those who wielded it as an instrument' (3). I had a book manuscript in my hand. I was almost an author. Obviously I had benefited from my research, but would any benefits flow the other way? Would I be just another person who was perceived as having done Parihaka over?

I recited my short mihi (talk) over and over in my head. I read and re-read my handwritten notes. I knew that if my chance came, and I was invited to speak inside Te Pae Pae (a meeting house), that I'd have to do it off the top of my head. 
We turned off onto mid-Parihaka Road and soon we were at Te Whiti's monument, right in front of the slab at Te Raukura. We were going to go on with dad's friend Tony Ruakere and his wife Anne. Then Lindsay Rihari McLeod joined us. He had opened Parihaka's evidence during the Waitangi Tribunal hearings in 1991 so he was one of the people I had spoken with in the archives. Our small group was called on first. Lindsay and my father spoke in Maori in the powhiri (welcome), then we walked around Te Pae Pae for the handshake, hongi and kiss. The atmosphere was generally warm but as I approached one kuia (female elder) I could hear her muttering: 'As if that's not enough, they have to take the bread from our mouths too...'.

I did get to speak and others responded, rebutting my arguments or putting their alternatives. At last I was getting a chance to defend my PhD, like they do in America! Eventually, the kuia got up. She repeated her comments about bread. 'They have taken our land,' she said slowly and forcefully, 'and now they want to take the bread from our mouths too'. The woman was looking down her nose at me with a frown or a grimace or maybe it was an ironic smile.

Stories keep us alive. They sustain us. Bread and breath. How much of a difference is there, really, between these two words? Stories feed us. This statement is more than metaphor as a proverb, ko te kai a te rangatira, he korero (the food of chiefs is talk) attests (Tau 12). In the absence of material wealth-land, money or taonga such as feather cloaks or greenstone ornaments - stories are the most significant treasure that people at Parihaka have left to hand on to their descendants. Kuia Parekaitu Tito made this point, explicitly, in an interview recorded for the 2000 City Gallery show, Parihaka: The Art of Passive Resistance. 'We haven't got anything to offer them at the moment except korero (talk)', Tito said (Hohaia 73-74).

That day at Parihaka, a different kuia had chosen her metaphor with care. Bread is an important part of the nineteenth-century Parihaka story but it is also part of much older Christian traditions too, in Bible stories about manna from heaven and loaves and fishes. The founders of Parihaka, Te Whiti and Tohu, were very familiar with the Bible. In about 1840, Te Whiti and Tohu had been baptised by Minarapa Te Rangihatuake, a freed Nga Puhi captive who built the first church in the Wellington region, the one near Te Aro pa in what is now central Wellington. The young leaders had returned to Taranaki with Te Rangihatuake in 1842 and they chose to attend the mission school that had been set up by Reformed Lutheran Missionary, Johann Freidrich Riemenschnieder at Warea. There they learnt more about the Bible. They also learnt about European agriculture - the crops and the machinery. Together they built and managed a flour mill at Warea (Riseborough, 'Resistance' 231-32). 
The ability to grow and harvest crops, to feed your own people but also to sell to white settlers, was crucial for Taranaki Maori as they (we) worked hard to resist the multiple pressures caused by war and by ballooning white settlement. In the wars of the 1860s, imperial troops had burnt villages and destroyed crops in north and south Taranaki. In the late 1870s, as the power and reputation of Parihaka grew, armed constabulary were again destroying Maori crops as they surveyed and then built the road to Parihaka. In early 1880, William Gordon sketched several mountains of bread piled on the floor and tables. 'Bread for Parihaka meeting in Dining Room Opunake Hotel Jan 16 1880', the caption says (Riseborough, 'Resistance' 240).

The men who invaded Parihaka in November 1881 were greeted by singing, dancing children and by women carrying '500 loaves they had made in the Parihaka bakery to feed their manuhiri, their visitors' ('Resistance' 244). The bread was warm. Who can resist the smell of fresh homemade bread? Who can resist the lure of a good story? But are all stories ours for the taking? Can we, as historians and writers, simply help ourselves to whatever stories we like the smell and taste of?

I'm not so sure that we can. As Arinia Loader has recently observed in her essay on her koroua (male elder), Maori history is about two seemingly opposed things: it is personal and it is about relationships, but it is also about 'casting the net wider'. Maori history is about whakapapa. Researchers need to take care to protect important relationships with the living and the dead. 'Maori history has its own internal ethics and ethics committees residing within us', Loader wrote (Loader 53).

After the kuia made her oblique comments about my work, the conversation inside Te Pae Pae moved on. A visitor was complimented on his beautiful Maori and there was a discussion about the Mongrel Mob's recent visit to the pa. Then Te Miringa stood up. 'I would like to say something else about Rachel's book. This korero (talk) is not taking the bread from people's mouths', he said. 'By sharing her korero she is putting the bread in people's mouths'.

I was shocked, thrilled, humbled and nourished by this statement. I had been facing the ethics committee and the chairman had decided to give my work the seal of approval. Needless to say, at the hakari (feast) afterwards, I found that many people wanted to speak with me. Outsider no more, my education had begun. I sought Te Miringa's guidance about my next research project and I had expected to enjoy many more challenging conversations with him, but this was not to be. On 17 August 2010, Te Miringa died, very unexpectedly, only 58 years old, an irreplaceable loss for everyone in Taranaki. His devastating death prompted me to share this story and to ask: If you are 'taking the bread from people's mouths' in your research - and aren't we all in some way - then 
what kind of sustenance are you offering in return? Is your work a theft or an exchange? Does your work profit from the suffering of others or does it relieve suffering? Who are you feeding with your work and why? Are you prepared to listen to these questions?

A week after Te Miringa's death I was in Aotearoa New Zealand to give a seminar at Victoria University's Stout Research Centre for New Zealand Studies and I learned that Te Miringa had been using some of the ideas and arguments in my book as he and other Taranaki leaders prepared for the forthcoming Treaty of Waitangi claim settlement negotiations with the Crown. This article - and the other ones I've written since the book - has been peer-reviewed by whanaunga (relatives) in Taranaki. My work has a new, more intimate and demanding, ethics review panel. Meanwhile, in a long but mixed review of The Parihaka Album on Radio New Zealand's Te Ahi Kaa program, Hiria Hammond and Maraea Rakuraku asked if my work was another example of outsiders telling Maori history. 'Where are the Maori voices in this book?' they wondered.

Maria Tumarkin: It seems that the deeper questions of ethics in academia have become so thoroughly bureaucratised that we are liable to be shocked by the idea that a historian could be seen as taking bread from people's mouths: a good historian, mind you, the one who plays by the rules, the one who is vigilant about her sources, extra-careful with her claims, sensitive to cultural idioms and imbalances of power, not in pursuit of any agenda beyond that of historical truths as she sees them. And to imagine this model historian-someone like Rachel Buchanan, someone like a great many of us at pains to do the right thing - accused, even if by one woman, even if in a way that is later powerfully retracted, of acting unethically, of taking rather than giving, is a heartbreaking undertaking. Because, really, what more could be asked of us?

I suspect that a response of hurt puzzlement, however explicable, owes a great deal to the way in which ethical questions have been outsourced to university ethics committees, buried in consent forms and cross-cultural protocols, in rules - both litigiously-minded and often smacking of sophistry - for human research conduct, which ensure that these days we are too busy wrestling with our fifty-page ethics applications to wrestle properly with ourselves. Yet most things that can be captured preemptively in forms and guidelines refer only to the most superficial kinds of injuries that historical practice may inflict. The ethics committee faced by Rachel Buchanan (faced by many of us at some point) has different kinds of transgressions in mind - trafficking in other people's stories, for instance, or the unexamined motives of practitioners, or the obsession with mining data or, often enough, that insidious habit of turning away from the reallife consequences of one's research. 
In some ways a modern researcher of the past is trained to be not unlike our deposed Prime Minister Kevin Rudd, who sincerely believed that the answer to every uncomfortable question, every personal failing and every ethical dilemma was simply to work harder. But what does working harder mean in the field of history? More often than not, it means gathering more empirical data (more interviews, more documents, more case-studies), drilling even more ferociously and single-mindedly into a particular historical moment or an archive. But why? Why should it strike us as self-evident that the more minute our knowledge of a particular historical context, the more honest and illuminating our insights about the past? Even if we know all there is to know about a particular moment or movement, does it automatically mean that the knowledge we have painstakingly gathered can and will put bread into a single person's mouth? Which is to say, will this knowledge repair or comfort, will it bring families together, can it cut through shame, can it make revisionism and falsification of the past harder to carry out with impunity?

Fetishised, the process of data extraction and accumulation (no matter how fluid and accommodating our notion of what constitutes this data) can easily blind us to the bigger questions of historical ethics and purpose - what do we believe the past actually does, what it is that we are doing when we engage with it, for what reason do we call out to the past, in whose name, what do we hope for, what do we stand to lose if the contact between the past and the present is momentarily or irretrievably broken?

When historians are encouraged to think of themselves as hunter-gatherers of sorts, what we get is the rise of Historian as a Debunker, a professional fingerpointer, a vigilante of sorts. This kind of a Historian (by no means a rare breed these days) uses her research to demonstrate that previous interpretations and definitive narratives of particular historical events fall apart in a more or less spectacular fashion under her extensive and enlightened scrutiny. Surely the culture of learned debunking, widely - and puzzlingly-accepted in the historical research, needs to be questioned at some length, not least for the kind of predatory instincts it implicitly encourages in those of us who do business with the past in relation to fellow practitioners and to the past itself.

There is another model too for the taking, Historian as a Disciplinarian, strict but fair, hard at work disciplining memory - giving detention to misbehaving memories caught playing up, keeping order in the noisy and uncouth pandemonium of competing narratives and interpretations. Just like the view of the Historian as Debunker, the Historian as a Disciplinarian provides yet another persuasive template of historical research, in which the deeper questions of ethics are side-stepped. In the end, both models misrecognise something fundamental about the nature of our responsibility to the past - the 
responsibility that goes well beyond diligent record-keeping, well beyond the best reflection and analysis we are capable of and right towards the maintenance of 'the bonds of mutual life-giving' between the past and the present (Rose).

In my childhood my grandmother on my father's side used to collect any stray bread crumbs her eyes could see. She would pick crumbs with her index or middle finger, finding them in all kinds of places - her plate or my plate, a kitchen table or a floor-and put them individually in her mouth. I grew up thinking most uncharitably of the intensity that surrounded my grandmother's relationship with bread. To me it was an unseemly obsession, creepy and annoying. Only years later, already in Australia and with my grandmother no longer alive, I understood her fixation on bread crumbs as a legacy of my grandmother's surviving the Holodomor - the Ukrainian famine of the 1930s, which, having claimed millions of lives, remained an unmentionable event for most of my grandmother's life.

I recognise now that my grandmother's handling of each crumb individually, the way bread called out to her, the pointillistic quality of the attention she lavished on it, was precisely how she carried the history and memory of her survival. She did so against the thick public silence, in which the history of the famine artificially engineered by Stalin, determinedly and vastly murderous in its intent, was buried. The memory of the famine lived in her body, first and foremost, in those fingers that reached out to every lost crumb so as to reclaim it and bring it back home, but it was also there in a myriad of inter-personal spaces and moments of contact, invisible to those (like me) who didn't know what my grandmother knew about the absolute irreplaceability of each crumb.

For me, who had no awareness of Holodomor for all the time that I lived in the same city as my grandmother, for all the time that we ate bread together, the realisation that I carried a kind of encoded memory of my grandmother's past and that this encoded memory was preserved (without being decoded or understood for decades) in a larger mnemonic archive of my childhood was a real moment of awakening. So much of the past is not always (or ever) ready to be seen or narrated, so much of the past does not even look like the past. It is passed on across generations not merely as stories or artifacts infused with tellable and extractable meanings, but as what Eva Hoffman called 'emanations' that are always on the verge of 'erupting in flashes of imagery' (Hoffman 9).

There has been quite a pronounced tendency automatically to think of this kind of past as traumatic because of how deeply it seems to be lodged inside us, how unpredictable and explosive its external manifestations sometimes are, but I think we should resist this tendency. Gabriele Schwab, for instance, draws on Derrida's notion of cryptonymy to suggest that the 'creation of cryptic enclaves in language marks the traces of refused mourning' (Schwab 4). My grandmother's 
secret and her inability to mourn has been, in other words, passed on to me through her silences and the way her silences were filled with crumbs of bread. 'Live burials of sorts, these crypts in the psyche and in language contain the secrets of violent histories, the losses, violations, and atrocities that must be denied' (4) and it is the descendants of survivors who live with and within these crypts. 'The traces this endocryptic identification leaves in language', Schwab concludes, 'can only be deciphered, de-crypted in a symptomatic reading, mindful of a secret in language' (4).

To decipher, to remember my grandmother's fingers anew with deep, piercing sadness instead of a fickle irritation, to remember them with love rather than with the blind denial of my grandmother's history, is finally to mourn what she could never mourn. Yes, that's true, but I don't think this is the whole story. I don't think we should be so reliant on the notion of 'trauma' to be able to conceive of the kind of past that refuses to be neatly channeled into delimited and definable texts, artifacts, rituals, representations and legacies. Our tendency to think with trauma obscures just how many of our personal and shared histories behave precisely in this manner, how many of them we carry in our bodies as a kind of an internal flora or a stomach lining perhaps, how many of these stories are kept alive, if not fully or at all knowable, in our daily acts and relationships, the extent to which the familial or communal structures of reciprocity and hostility are created and sustained by these very histories. In the end, the past that sits on the tip of people's tongues ready to be turned into a story, the past cocooned in archives and photo albums ready to be seen, the past that gets a ritualised airing once a year at an anniversary or a commemoration ready to be paraded around, in other words, the kind of the past that is always ready to manifest itself as the past, is only the starting point for writing history.

Rachel Buchanan: Maria Tumarkin's story about her grandmother's obsession with crumbs invites us to think differently about where we get our information from and about where information might be stored and about how we, as researchers interested in the past, might access this information. This is especially critical for researchers working on the past in totalitarian regimes where many records have either been falsified or destroyed. Maria Tumarkin demonstrates that one way to get around this destruction or repression is to broaden the archive. She has described, so movingly, how her grandmother's annoying and embarrassing habit of picking up crumbs was actually a historical re-enactment, a performance in memory of famine. Is it possible to think of her grandmother as an archive - not as someone whose memories can be extracted by a skilful oral history interviewer-but as something more than that, as someone whose actions, inactions, words, silences, appearances and choices are all records worthy of examination? 
I think my grandmother Rawinia Queenie Agnes Buchanan's life (especially her obsessions with manners, appearances and secret property acquisition) can be read as evidence of the destructive power of assimilationist policies in New Zealand, of the power of blood quantum laws to shape identities, of the doublesided shame associated with being Maori or not being Maori enough (Buchanan, Parihaka Album, 203-234). Like Maria, I have used this very small story (about my grandmother's obsession with appearances, for example) to talk about some very big stories (colonisation, assimilation, indigenous resistance). It is exciting to switch modes and to try out the idea that rather than seeking to examine many archival collections and touch many thousands bits of old paper, rather than trying to be ever more disciplined through exhaustive archival one-upmanship - mine was bigger than yours, more remote, harder to translate, more chaotic, never before discovered, not even catalogued or I created my own archive by doing so many dozens of interviews - you might decide, eventually, to scale things back a bit and consider one piece of evidence only. A grandmother, say. Or, a week's worth of entries in a diary (Nugent). A few years ago I heard the brilliant Dutch archivist Eric Ketlaar sum up a two-day conference on minority voices in the archives. He advised speakers against moving on to a new topic. Instead, he said, we should re-examine our papers, refine them and focus more tightly on just one aspect of our pet archives.

It is archivists, of course, who provide historians with our 'bread and butter' the diverse, precious collections we work with. To make ethical history, we need to be as self-conscious as Maria Tumarkin is about the limitations (and possibilities) of the evidence we are working with. We also need to think about the role of archivists as 'secret historians', as the first authors of the histories we make. My experience researching Parihaka taught me that Maori in Taranaki have made strategic decisions to present testimony at commissions of inquiry so that their (our) histories would be on the public record too. As Australian archivist and historian Joanna Sassoon has argued, 'It is incumbent on historians to search for analytical tools to explore the symbiotic relationship between archival memory and the craft of history' ('Phantoms of Remembrance' 40). Further, Sassoon wants to challenge the idea that 'the discovery of new information and new evidence is a prerequisite for writing history. Sometimes the absence of direct evidence can lead to more imaginative uses of historical sources, and has the potential to lead to new kinds of histories' ('Chasing Phantoms' 116), such as the ones written by Maria Tumarkin.

It is sobering to remember that archives contain no more than the crumbs of the past anyhow. As Terry Cook notes, state archives around the world select 'for long-term preservation as society's memory roughly 1-5 per cent of the 
total documentation of major institutions and considerably less from private citizens' (Cook 169). Given this, writers needed to work on better integrating the archivist (the subject) with the records (the object) (Cook 179).

Ideally, this knowledge should force us to move beyond an obsession with archives as the seat of empirical, objective, scientific and absolute truth - an obsession that has fuelled the so-called history wars in Australia- to a more sophisticated and interesting position in which our history-making also carefully considers what Francis Blouin and William Rosenberg have called 'the task of appraisal, acquisition, classification and description' (851). Ideally, such knowledge should force us to broaden, quite radically, what might be considered evidence to include, for example, grandmothers and their annoying little habits.

Derrida's exciting 1996 speech, 'Archive Fever', invites even those researchers who work exclusively in conventional, state-run archives, to acknowledge that what they are doing involves intuition and creativity as well as logic and analysis. In their introduction to 'Archives and Archiving', Part I of the collection of papers produced by the Sawyer Seminar on archives, Blouin and Rosenberg argued that participants had two responses to Derrida's intervention and the subsequent 'archival turn' in humanities research. One participant, Carolyn Steedman, asserted that the value of Derrida's intervention was 'in its turn to the historical subjective, the realm of emotions, feelings, and experiences that clearly affect the ways both individual and social pasts and presents are understood but whose access lies elsewhere than in the archive' (1).

However, Steedman argued that archives were not like human memory and that there was actually not that much there in the archives, that the bundles of material they contained were benign and lifeless, sitting there waiting to be narrativized by 'the historian, the user, the social rememberer [who] gives the archives its meaning' (1).

But others disputed this view. Ketlaar has described archives not as 'dead masses of paper but living matter, intervening, directly, in the lives of hundreds of thousands of people' (17), while archival ethnographer Laura Ann Stoler says archives have a 'pulse' (52). The archivists who presented at the Sawyer seminar went further. In the introduction to Part II, Blouin and Rosenberg said participants described archiving as far more than the preservation of knowledge. They said an understanding of the past was being shaped 'by direct and indirect intervention and mediations by archivists at all levels'. (86). Some even said the present moment was a 'very active phase in archival intervention, one that can be described as beyond postcustodial, in which the processes of selection, access and even description are increasingly structured by particular cultural values, social biases and political inclinations' (86, emphasis in original). Of course, the creation of archives - via selection, access and description-has always been 
shaped by cultural, political and individual biases. What is different now is that institutions and their staff are, ideally, aware of these biases and working to create holistic, challenging collections that document many perspectives, even unpalatable or unpopular ones, on a particular event. The National Library's Forgotten Australians Project is an exemplar of what has been described as archival 'memory activism' (Sassoon, 'Memory for justice' 25).

Archives grow through selection, rejection, exclusion and destruction. The remembering of the archive is built on a much larger process of forgetting. Writing about archiving and architecture, Kent Kleinman said: 'The archive is more accurately described as a machine for forgetting' (55).

Ethical practice should be a concern and challenge for all researchers, not just those of us writing about our families or about marginalized, colonized or abused groups of people. Every source we work with, living and dead, visible and invisible, relative or foreign, has a pulse. If we want our work to be fresh rather than stale, then we need to respect this.

Maria Tumarkin: In 'order to be knowingly in each others' presence', writes one of the foremost cultural anthropologists of our time, Johannes Fabian,

we must somehow share each others' past. To put this provocatively, I am convinced that only when they get to a point where they begin to 'remember the present' will self and other be drawn into a process of mutual recognition based on the kind of knowledge that changes the knower and that by the same token reconstitutes his or her identity. (68)

Most of our historical projects do not change us or, at the very least, they do not change us enough, not least because they tend to the past, which is extractable and extrapolateable, explicit, rather than implicit, discrete rather than diffused. These kinds of projects are, of course, much easier to undertake, but it doesn't mean that we need to settle for them or for the implicit boundaries that they propose about what it is that we are meant to be interested in as historians. How much more interesting it would be to try to connect to - and to write about the past that is lodged deeply within bodies, families and communities, the past that is the bread in people's mouths, that is the silently collected crumbs under their fingertips. I read and re-read Deborah Rose's words:

Our boundaries around what is sayable, and our elisions that treat as real only that which can be subject to constricted modes of social analysis, have the potential either to either excise a great range of experience and knowledge, or to drag it back into the familiar, thus depriving it of its own real power. (97) 
As people who think with and about the past, we have responsibility to that power. To honour it we must produce the kind of work that acknowledges in its every breath the fact that the webs of connectivity and kinships produced by the past - the hauntings, the forces and the archives of all kinds - are real things that exist in the real world and continue to affect real people.

In a review of Clifford Geertz's posthumous collection of essays in TheAustralian, historian Inga Clendinnen wrote that Geertz's work was revelatory: it married 'intense intellectual inquiry to exhilaration'. For any intellectual work to be revelatory (and why shouldn't we aim for that as opposed to something that is the academic equivalent of meat and two veg-scholarly rigour), it needs to leave space for its author herself to experience revelations. For any work to be exhilarating, it needs to be exhilarating - not always but sometimes - to write. This exhilaration can of course come from different places; in my case it was the realisation - the one I share with Rachel Buchanan and the one that has compelled us towards this collaboration - that the search for a historical truth is always at the same time the search for a personal truth as well.

When I was writing my first book, I was resistant for a long time to putting myself into the story. I was taught, after all, that real historians never cry or laugh in their work, that their identity and the personal stakes they may have in their work should, for the most part, be covered up in the interest of good history and good taste. I was taught that you take the all-important energy from the historical material by putting too much of yourself in. What I discovered was that I could not communicate the essence of my ideas and insights (this book explored the fate and power of physical sites of trauma across the world), that I could not do justice to the subject matter without making explicit what was at stake for me. Instead of hiding from my readers, I found it essential - and exhilarating - to stand in their full view.

I still remember the first academic book that made me cry-Avery Gordon's Ghostly Matters. What a relief it was to be so deeply and personally affected by a book of scholarship and to realise that you can, in fact, produce a work of great intellectual weight and startling originality, meticulously researched, rich in sources and theoretical apparatus, but also with its author powerfully present on its pages - emotional, vulnerable, deeply and obviously affected by her research and ideas. Revelatory, exhilarating, transformative - we rarely hear these words in History Departments, but why not? Why shouldn't we want our research and writing to be described in those terms? Why shouldn't our identity as practitioners of history in its aspirational form, when we lie on our beds, when we imagine our future, when we throw ourselves into our research, be directly connected to words just like that? As readers, these are the kinds of history we want to read, so why don't we want to write them? We are offered many possible identity templates as historians: we can be glorified bureaucrats, 
debunkers, disciplinarians or hunter-gatherers. Yet none of these possibilities feel even remotely appealing to me. Certainly none rings true. But should we choose to go back to the story at the heart of this essay, to the question that this story asks of us, which is both confronting and deeply liberating - Who and what are we feeding with our work and why? - then I think we can begin imagining the kind of history writing that might, over time, end up putting bread (one crumb at a time) back into people's mouths.

Rachel Buchanan (Taranaki, Te Ati Awa, Ngati Ruanui) is an honorary resident scholar at Victoria University, Wellington's Stout Research Centre

Maria Tumarkin is a Melbourne-based writer and cultural historian.

\section{Works Cited}

Binney, Judith. Encircled Lands: Te Urewera, 1820-1921. Wellington: Bridget Williams Books 2009.

- ' 'History and Memory: The Wood of the Whau Tree, 1766-2005.' The New Oxford History of New Zealand. Ed. Giselle Byrnes. Melbourne: Oxford UP, 2009. 73-98.

-. 'Maori Oral Narratives, Pakeha Written Texts: two forms of telling history.' New Zealand Journal of History 21.1 (1987): 16-28.

—. Nga Morehu: The Survivors. Auckland: Oxford UP, 1986

- Redemption Songs: The Life of Te Kooti Arikirangi Te Turuki. Auckland: Auckland UP and Bridget Williams Books, 1995.

- - and G. Chaplin. 'Taking the Photos Home: The recovery of a Maori history.' Visual Anthropology 4 (1991): 431-442.

-, G. Chaplin \& C. Wallace. Mihaia: The Prophet Rua Kenana and his Community at Maungapohatu. Wellington: Oxford UP, 1986.

Buchanan, Rachel. 'The Parihaka Album-and Flossie.' Mana Magazine 92 (2010): 72-73.

—. 'Recycling Doctoral Waste.' History Australia 7.1 (2010): 11.1-11.9.

—. The Parihaka Album: Lest We Forget. Wellington: Huia, 2009. 
Blouin, Francis X. and William G.Rosenberg. 'Introduction to Part I Archives and Archiving' and 'Introduction to Part II Archives in the Production of Knowledge.' Archives, Documentation and Institutions of Social Memory: Essays from the Sawyer Seminar. Ed. Francis X. Blouin and William G. Rosenberg. Ann Arbor, Mich: U of Michigan P, 2006. 1-3; 85-88.

Clendinnen, Inga. 'The Ideal Humanist.' Review of Life Among the Anthros and Other Essays by Clifford Geertz. The Australian, 1 September, 2010. <http://www.theaustralian.com.au/arts/books/the-ideal-humanist/storye6frg8nf-1225911729432>. Accessed 4 June 2012.

Cook, Terry. 'Remembering the Future: Appraisal of Records and the Role of Archives in Constructing Social Memory.' Archives, Documentation and Institutions of Social Memory: Essays from the Sawyer Seminar. Ed. Francis X. Blouin and William G. Rosenberg. Ann Arbor, Mich: U of Michigan P, 2006. 169-181.

Derrida, Jacques. Archive Fever: A Freudian Impression. Chicago: U of Chicago P, 1996.

Fabian, Johannes. 'Remembering the Other: Knowledge and Recognition in the Exploration of Central Africa.' Critical Inquiry 26.1 (1999): 49-69.

Hammond, Hiria, and Maraea Rakuraku. Review of The Parihaka Album, Radio New Zealand National Te Ahi Kaa, 22 Haratua (May) 2010. Podcast available at <http://www.radionz.co.nz/national/programmes/teahikaa/20100523>. Accessed 27 Oct. 2010.

Hoffman, Eva. After Such Knowledge. Memory, History, and the Legacy of the Holocaust. New York: Public Affairs, 2005.

Hohaia, Te Miringa. 'Ngaa Puutaketanga Koorero Moo Parihaka.' Parihaka: The Art of Passive Resistance. Ed. Te Miringa Hohaia, Gregory O'Brien and Lara Strongman. Wellington: Victoria UP, 2000. 42-65.

Ketlaar, Eric. The Archival Image: Collected Essays. Hilversum: Verloren, 1997.

Kleinman, Kent. 'Archiving/Architecture.' Archives, Documentation and Institutions of Social Memory: Essays from the Sawyer Seminar. Ed. Francis X. Blouin and William G. Rosenberg. Ann Arbor, Mich: U of Michigan P, 2006. 54-60.

Loader, Arini. 'Casting the Net Wider: Native American Literary Nationalism in Aotearoa.' Te Pouhere Korero 4 (2010): 51-60.

Mahar, Caitlin. 'Oral History Meets The Media: An Historian's Excursion into Radio Land'. Circa: The Journal of Professional Historians 1 (2010): 3-8. 
Mahuika, Nepia. 'Korero Tuku Iho: Our Gift and Our Responsibility.' Te Pouhere Korero 4 (2010): 24-40.

Nugent, Maria. Captain Cook Was Here. Melbourne: Cambridge UP, 2009.

Phillipson, Grant. Preparing Claimant Evidence for the Waitangi Tribunal. Wellington: Waitangi Tribunal, 1999.

-. 'Talking and Writing History: Evidence to the Waitangi Tribunal.' The Waitangi Tribunal Te Roopu Whakamana i te Tiriti o Waitangi. Ed. Janine Hayward and Nicola R. Wheen. Wellington: Bridget Williams Books, 2004. 41-52.

Pinter, Harold. 'Art, Truth \& Politics.' Nobel Lecture, Nobel Prize in Literature 2005. <http://www.nobelprize.org/nobel_prizes/literature/laureates/2005/ pinter-lecture-e.html >. Accessed 18 June 2012.

Riseborough, Hazel, 'A New Kind of Resistance: Parihaka and the Struggle for Peace.' Contested Ground: Te Whenua I Tohea. The Taranaki Wars, 1860-1881. Ed. Kelvin Day. Wellington: Huia, 2010. 230-253.

- Days of Darkness: The Government and Parihaka Taranaki, 1878-1884, 2nd ed. Auckland: Penguin, 2002.

- 'Parihaka and the historians.' Parihaka: Te Niho o Te Ati Awa. Parihaka Seminars 1 (1993).

Rose, Deborah Bird. 'Recursive Epistemologies and an Ethics of Attention.' Extraordinary Anthropology. Transformations in the Field. Ed. Jean-Guy A. Goulet and Bruce Granville Miller. Nebraska: U of Nebraska P, 2006. 88-102.

Sassoon, Joanna. 'Chasing Phantoms in the Archives: The Australia House Photographic Collection.' Archivaria 50 (2000): 117-124.

-. "Memory for justice" or "Justice for memories": Remembering forgotten Australians and former child migrants.' Archifacts (2010): 25-34.

- 'Phantoms of remembrance: libraries and archives as 'the collective memory.' Public History Review 10 (2004): 40-60.

Scott, Dick. Ask That Mountain: The Story of Parihaka. Auckland: Reed/ Southern Cross, 1975.

Schwab, Gabriele. Haunting Legacies: Violent Histories and Transgenerational Trauma. New York: Columbia UP, 2010.

Smith, Linda Tuhiwai. Decolonizing Methodologies: Research and Indigenous Peoples. Otago: U of Otago P, 1999. 
Stoler, Laura Ann. Along the Archival Grain: Epistemic Anxieties and Colonial Common Sense. New Jersey: Princeton UP, 2009.

Tau, Rawiri Te Maire. 'Tirohia Atu Nei Ka Whetu Rangitia, Minding the Past.' Te Pouhere Korero 5 (2011): 7-31.

Tumarkin, Maria. Otherland. Sydney: Random House, 2010.

—. Traumascapes. Melbourne: Melbourne UP, 2005. 